\title{
Identification of New Translocations Involving ETV6 in Hematologic Malignancies by Fluorescence In Situ Hybridization and Spectral Karyotyping
}

\author{
María D. Odero, '* Katrin Carlson, ${ }^{2}$ María J. Calasanz,' Idoya Lahortiga,' Vandana Chinwalla, ${ }^{2}$ \\ and Janet D. Rowley ${ }^{2}$ \\ 'Department of Genetics, University of Navarra, Pamplona, Spain \\ ${ }^{2}$ Department of Medicine, Section of Hematology/Oncology, University of Chicago, Chicago, Illinois
}

TELIETV6 is the first transcription factor identified that is specifically required for hematopoiesis within the bone marrow. This gene has been found to have multiple fusion partners; 35 different chromosome bands have been involved in ETV6 translocations, of which 13 have been cloned. To identify additional ETV6 partner genes and to characterize the chromosomal abnormalities more fully, we studied bone marrow samples from patients known to have rearrangements of $12 \mathrm{p}$, using fluorescence in situ hybridization (FISH) and spectral karyotyping (SKY). FISH analysis was done with I4 probes located on $12 p|2$.$| to 12 p \mid 3.3$. Nine ETV6 rearrangements were identified using FISH. The aberrations include $t(1 ; \mid 2)(p 36 ; p \mid 3)$,

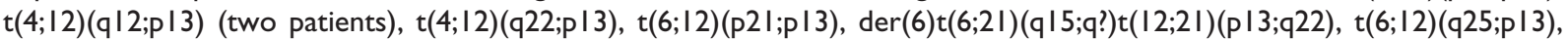
$\operatorname{inv}(\mid 2)(p \mid 3 q 24)$, and $t(2 ; 2 ; 5 ;|2 ;| 7)(p 25 ; q 23 ; q 3|; p| 3 ; q \mid 2)$. Six new ETV6 partner bands were identified: Ip36, 4q22, 6p2I, $6 q 25,12 q 24$, and $17 q \mid 2$. Our present data as well as previous data from us and from other researchers suggest that ETV6 is involved in $4 \mathrm{I}$ translocations. The breakpoints in ETV6 were upstream from the exons coding for the HLH (helix-loop-helix) domain in six cases. Although cytogenetic analysis identified $12 \mathrm{p}$ abnormalities in all cases, FISH and SKY detected new and unexpected chromosomal rearrangements in many of them. Thus, complete characterization of the samples was achieved by using all three techniques in combination. (c) 200I Wiley-Liss, Inc.

\section{INTRODUCTION}

TEL (translocation-E26 transformation-specificleukemia), also called ETV6, is the first transcription factor identified that is required specifically for hematopoiesis within the bone marrow (Wang et al., 1998). This gene frequently is rearranged in translocations in a wide spectrum of human leukemias (Mitelman, 1998), with the same fusion transcript in both myeloid and lymphoid leukemias (Peeters et al., 1997a). ETV6 has been found to have many fusion partners. Using fluorescence in situ hybridization (FISH), 35 different chromosome bands have been shown to be involved in ETV6 translocations, of which 13 have been cloned: ARNT (1q21), ARG (1q25), MDS1/EVI1 (3q26), CHIC2/BTL (4q12), ASC2 (5q13), PDGFRB (5q33), STL (6q23), JAK2 (9p24), ABL (9q34), CDX2 (13q12), TRKC (15q25), CBFA2 (21q22), and MN1 (22q11) (Golub et al., 1994, 1995; Romana et al., 1995; Buijs et al., 1995; Papadopoulos et al., 1995; Peeters et al., 1997a,b; Suto et al., 1997; Cazzaniga et al., 1999; Chase et al., 1999; Cools et al., 1999; Eguchi et al., 1999; Yagasaki et al., 1999; Iijima et al., 2000; Salomon-Nguyen et al., 2000). The ETV6 protein contains two critical domains, the $5^{\prime}$ helixloop-helix (HLH) dimerization domain (coded for by exons 3 and 4) and the 3' E26 transformation- specific (ETS) DNA-binding domain (exons 6 to 8). Little is known about the function of the central region of ETV6. The translocation breakpoints are distributed throughout the gene, and ETV6 contributes to the pathogenesis of leukemia by remarkably diverse molecular mechanisms that are only partially understood.

To identify additional ETV6 partner genes and to characterize the chromosomal abnormalities more fully, we studied bone marrow samples from patients known to have rearrangements of $12 \mathrm{p}$, using three different techniques: G-banding, FISH, and spectral karyotyping (SKY). Nine patients with ETV6 rearrangements were identified by FISH. Although cytogenetic analysis pinpointed $12 \mathrm{p}$ abnormalities in all cases, FISH and

Supported by: Departamento de Salud del Gobierno de Navarra; Fundacion Empresa-Universidad de Navarra; National Cancer Institute; Grant number: CA42557; G. Harold and Leila Y. Mathers Charitable Foundation; Spastic Paralysis Foundation; Illinois-Eastern Iowa District of Kiwanis International.

*Correspondence to: María D. Odero, M.D., Ph.D., Department of Genetics, University of Navarra, C/Irunlarrea s/n, 31008-Pamplona, Spain. E-mail: modero@unav.es

Received 11 September 2000; Accepted 7 November 2000

Published online 30 March 2001 
SKY detected new chromosomal rearrangements in many of them.

\section{MATERIALS AND METHODS}

\section{Patients}

Fifteen patients with hematologic malignancies and $12 p$ balanced translocations or add(12p) studied at the University of Chicago (U.S.A.) and at the University of Navarra (Spain) were included in the present report. Of these patients, four were studied at diagnosis and 11 at relapse. All samples were obtained with informed consent.

\section{Fluorescence In Situ Hybridization}

Cytogenetic studies were done on unstimulated short-term bone marrow cultures. G-banded karyotypes were described according to the ISCN (Mitelman, 1995). FISH analysis was done using 11 cosmid and three phage probes located on $12 \mathrm{p} 12.1$ to 12p13.3. TEL/ETV6 was analyzed by 179A6 (exon 1), 50F4 (exon 2), 54D5 (exons 5-8), and 148B6 (exon 8) (all kindly provided by Dr. Peter Marynen, Center for Human Genetics, University of Leuven, Leuven, Belgium) and by a cosmid contig that contained about $60 \mathrm{~kb}$ of genomic sequences surrounding exon 3 (TEL 11/18). Two 90-kb P1 phage clones that contained KIP1/CDKNIB were used to analyze this gene (Pietenpol et al., 1995) (addresses: 2096 and 2097; Genome Systems, Inc). The order of these probes was telomere-D12S235-D12S237-Phage L24A-D12S229-HTY3049c17-D12S133-179A6-50F4-TEL11/18-54D5-148B6-P12096-P12097-D12S119-D12S20-centromere (Kobayashi et al., 1994; Baens et al., 1996). Three PACs assigned to 4q11-q12 (238H24, 200D9, and 1146G14) (provided by Dr. Peter Marynen, Center for Human Genetics, University of Leuven, Leuven, Belgium) were used to check the involvement of CHIC2/BTL in cases with $\mathrm{t}(4 ; 12)$.

Additional FISH experiments were performed using whole-chromosome painting probes (WCP) for chromosomes $6,7,11,12$, and 13 , or centromerespecific probes (CEP) direct labeled with Spectrum Green ${ }^{\circledR}$ or Spectrum Orange ${ }^{\circledR}$-dUTP (Vysis, Downers Grove, IL). In case 8, we used the LSI TELAML1 probe to determine whether CBFA2/AML1 was involved (Vysis). The probes were labeled with biotin-11-dUTP or digoxigenin-11-dUTP (Boehringer-Mannheim, Indianapolis, IN) using nick translation and were hybridized to the patients' slides as previously described (Rowley, 1990). The biotin-labeled probes were detected with fluorescein isothiocyanate (FITC)-conju- gated avidin. The digoxigenin-labeled probes were detected with rhodamine-conjugated sheep anti-digoxigenin antibodies (Boehringer-Mannheim). Chromosomes were identified using counterstaining with 4'6-diamidino-2-phenylindole dihydrochloride (DAPI). The presence or absence of the FISH signals was scored on an average of 12 abnormal metaphase cells (range, 7-20) per probe per patient. Images of the hybridized cells were captured with a liquidcooled, charge-coupled device camera (Photometrics, Tucson, AZ). Separate gray-scale images for the DAPI and the FITC fluorescence were acquired. The images were merged using Adobe Photoshop (Adobe Systems Inc, San Jose, CA) on a Macintosh computer (Apple Computers, $\mathrm{Cu}-$ pertino, CA).

\section{Spectral Karyotyping Analysis}

The SKY probe mixture and hybridization reagents were obtained from Applied Spectral Imaging (Carlsbad, CA). Slides for spectral karyotyping were hybridized with the probe cocktail as previously described (Rowley et al., 1999) for 2 days at $37^{\circ} \mathrm{C}$. For each case, between six and 12 metaphase cells were captured and analyzed, using the SD200 system (Applied Spectral Imaging). Cases with questionable or not obvious chromosome rearrangements were analyzed further using the appropriate painting or centromere-specific probes $(\mathrm{Vy}-$ sis).

\section{RESULTS AND DISCUSSION}

Nine of the 15 patients with $12 p$ balanced translocations $(60 \%)$ had rearrangements of the ETV6 gene. These patients had various hematologic malignancies, including four cases of acute myeloid leukemia (AML), three of myelodysplastic syndromes (MDS), one of acute lymphoblastic leukemia (ALL), and one of chronic lymphocytic leukemia. The $12 p$ aberrations were the sole abnormality only in case 2. Eight $12 \mathrm{p}$ translocations affecting the ETV6 gene were identified. The aberrations included $\mathrm{t}(1 ; 12)(\mathrm{p} 36 ; \mathrm{p} 13)$, $\mathrm{t}(4 ; 12)(\mathrm{q} 12 ; \mathrm{p} 13)$ (two patients), $\mathrm{t}(4 ; 12)(\mathrm{q} 22 ; \mathrm{p} 13), \mathrm{t}(6$; 12)(p21;p13), der(6)t(6;21)(q15;q?)t(12;21)(p13;q22), $\mathrm{t}(6 ; 12)(\mathrm{q} 25 ; \mathrm{p} 13)$, inv(12)(p13q24), and $\mathrm{t}(2 ; 2 ; 5 ; 12 ;$ 17)(p25;q23;q31;p13;q12) ('Table 1). Six new partner bands were identified: 1p36, 4q22, 6p21, 6q25, 12q24, and $17 \mathrm{q} 12$. FISH results are summarized in Table 2. Although some of these abnormalities had been detected previously using G-banding, this is the first study reporting ETV6 involvement in these rearrangements. 


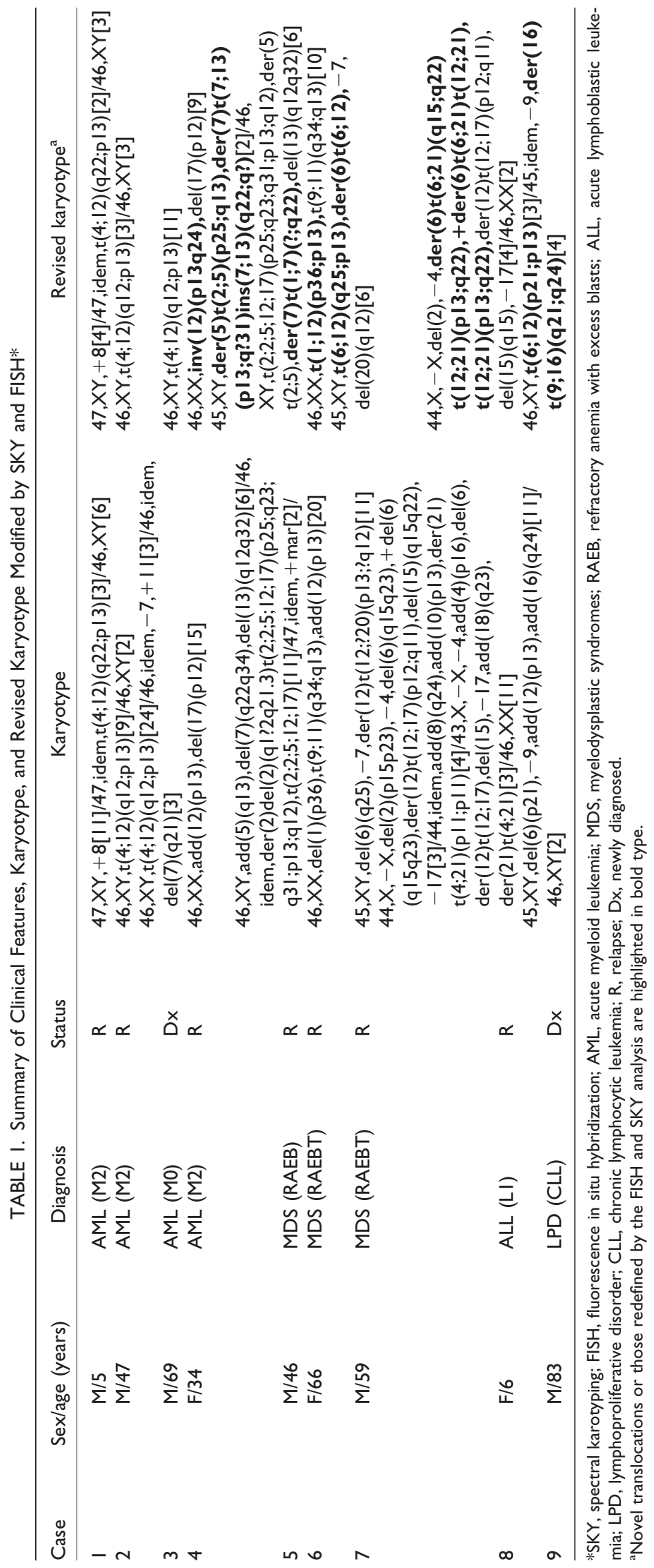


TABLE 2. Results of FISH Analysis with ETV6 Specific Cosmid Probes*

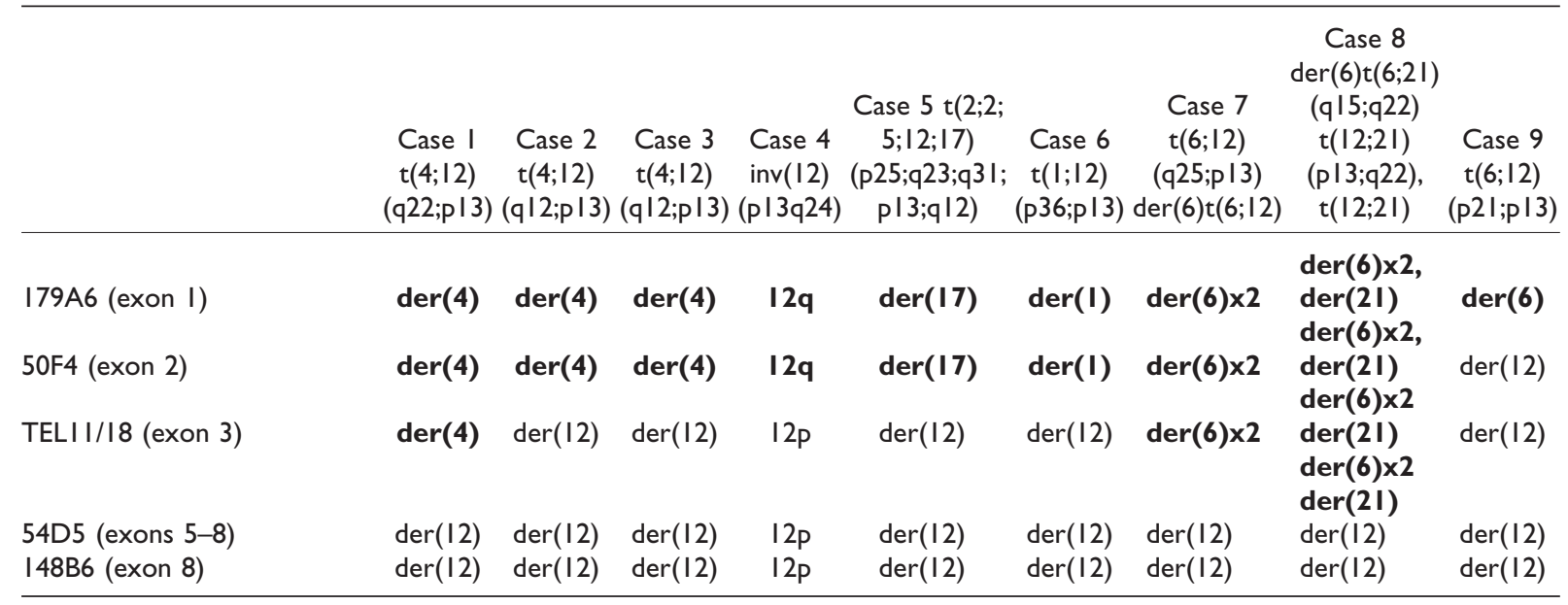

*FISH, fluorescence in situ hybridization.

The chromosome location of TEL translocation is indicated in bold type.

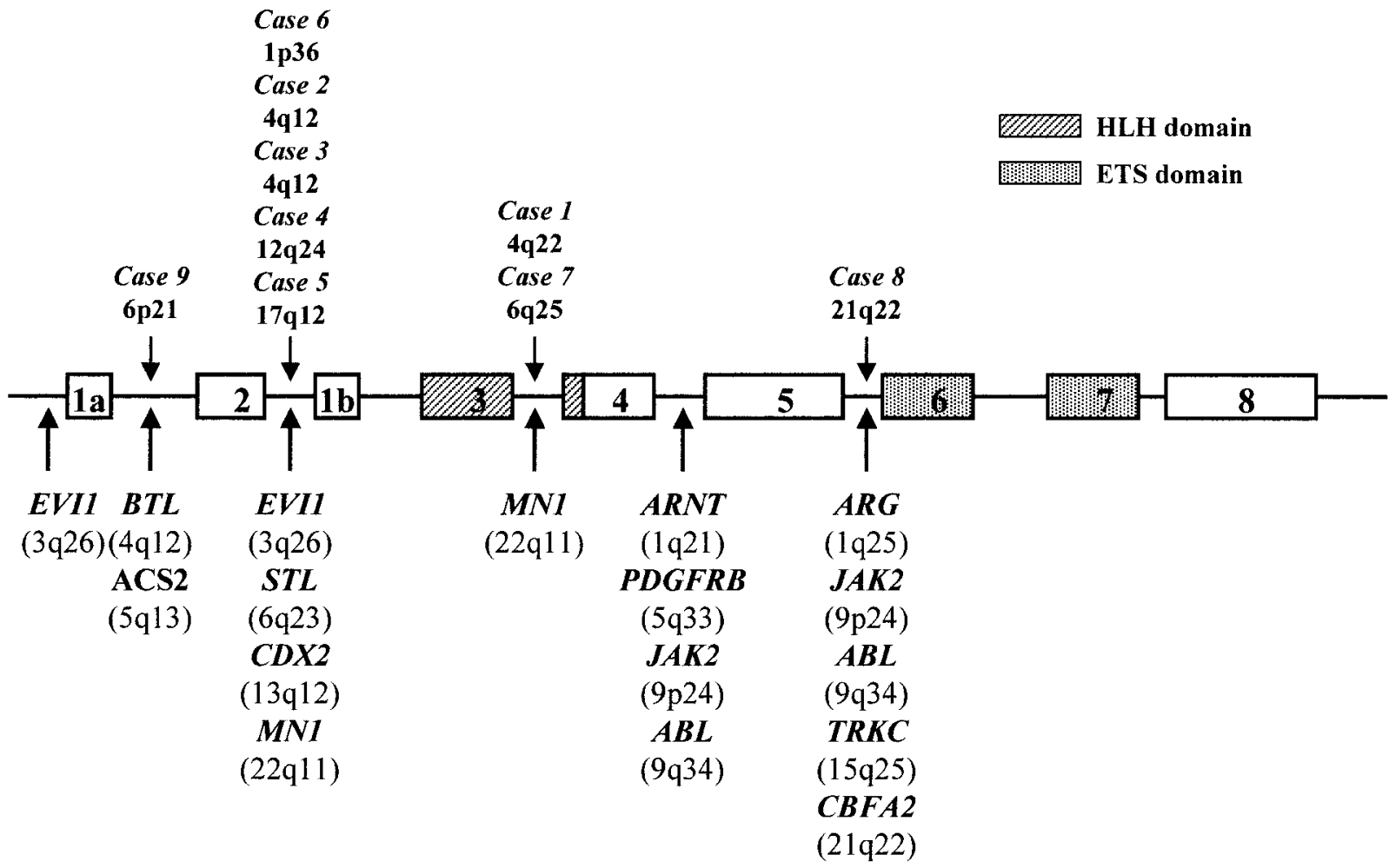

Figure I. Diagram of the ETV6 gene showing the exons (numbered rectangles) and the protein domains. The location of the breakpoints in patients in this report are above the line; the location of the breakpoints in ETV6 in the cloned translocations already published is shown below the line.

In addition to confirming the FISH results, SKY allowed for the complete characterization of the karyotype of the leukemia samples. In cases 5,8 , and 9, additional FISH experiments were performed using chromosome painting and centromere probes to confirm complex translocations.
The revised karyotypes summarizing the G-banding, FISH, and SKY results are shown in Table 1. FISH and SKY confirmed the G-banding results in cases 1,2 , and 3 . The $t(4 ; 12)$ found in cases 2 (AML-M2) and 3 (AML-M0) seems to be the same translocation reported by Cools et al. (1999) that 

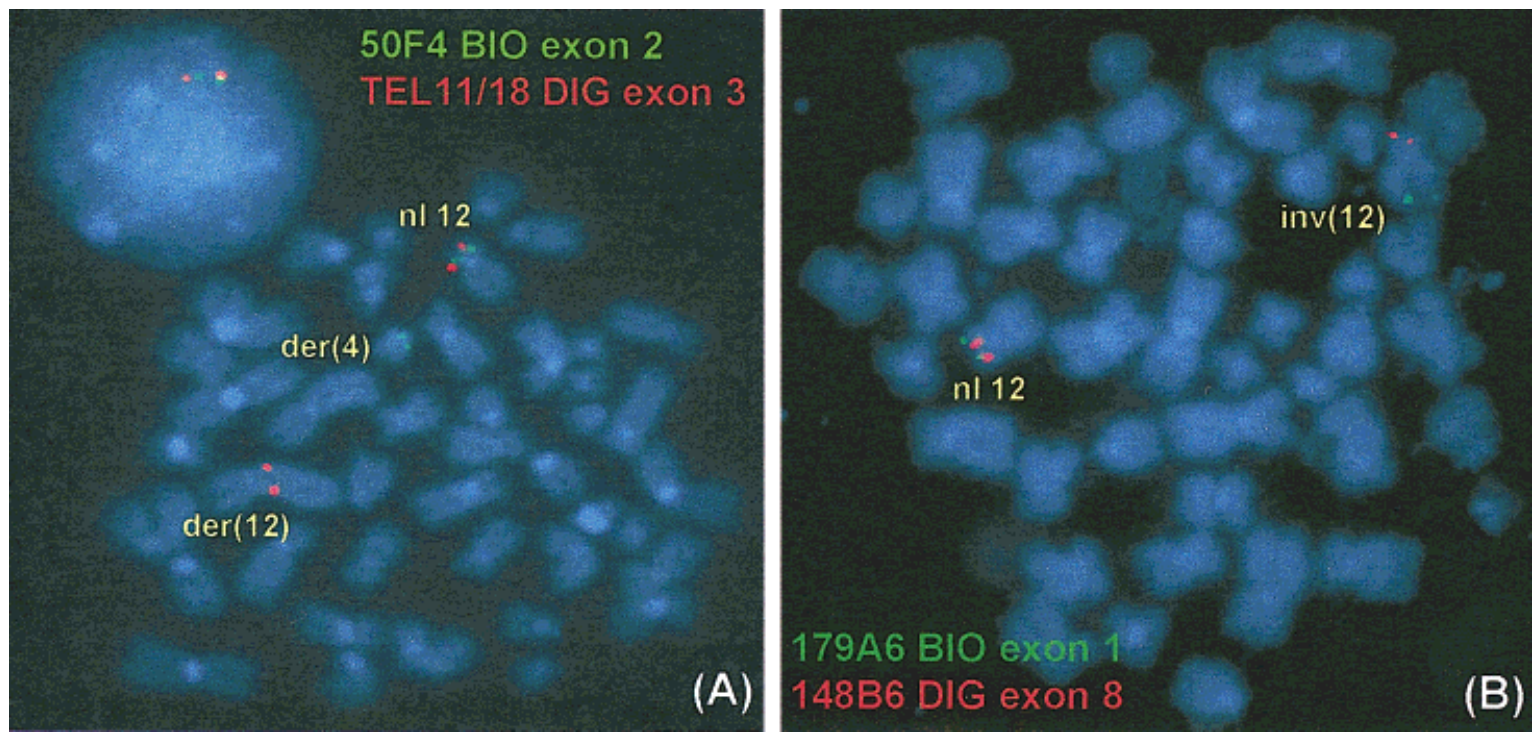

Figure 2. Examples of fluorescence in situ hybridization analysis of ETV6 rearrangements. A: Patient 2 with a $t(4 ; 12)(q|2 ; p| 3)$. The red and green signals both label the normal $12 p$, whereas the green signal representing the telomeric probe is translocated to the $\operatorname{der}(4)$ and the red centromeric probe labels the $\operatorname{der}(12)$ chromosome. B: Patient 4 with inv(I2)(pI3q24). The red and green signals are together on the normal I2p, and they are separated on the inv $(12)$, with exon 8 remaining on I2p and exon I labeling I2q.

fuses ETV6 and CHIC2/BTL. In both cases the breakpoint was in intron 2 of ETV6 (Fig. 2), upstream from the exons coding for the HLH domain, and in intron 3 of CHIC2/BTL. Only four other cases with this rearrangement have been reported: three were classified as AML-M0 and one as myeloid/natural killer (NK) cell leukemia (Cools et al., 1999). Although more FISH studies are required to confirm the involvement of these genes in cases with $\mathrm{t}(4 ; 12)$, the CHIC2-BTL-ETV6 fusion gene could be specific for an early hematopoietic cell phenotype in AML.

Our case 2 seems to be similar to case 4 described by Cools et al. (1999). The breakpoint in ETV6 is between exon 2 and 3 in both cases, and we were unable to detect a CHIC2-BTL-ETV6 fusion transcript in the RNA of the patient (data not shown). In case 1 , the breakpoint in chromosome 4 was on $4 \mathrm{q} 22$, and FISH confirmed that it was telomeric to CHIC2/BTL. In cases 4 and 6, the translocation of 12 p13 with an unknown chromosome resulted in an inv(12)(p13q24) (Fig. 2) and a $\mathrm{t}(1$; 12)(p36;p13). The breakpoint was between exons 2 and 3 in both cases. Identification of the new fusion partner genes is in progress. There are several candidate genes on 1p36. Among the candidate genes on $12 \mathrm{q} 24$ are PRKAB1 (protein kinase, AMP-activated, beta 1 non-catalytic subunit) and CIT.

In three cases, additional studies using FISH and SKY resulted in a deletion 6 identified by G-banding, which is more accurately described as a translocation with chromosome 12: $\mathrm{t}(6 ; 12)$ (cases 7 and 9) and $\operatorname{der}(6) \mathrm{t}(6 ; 21) \mathrm{t}(12 ; 21)$ (case 8$)$. The breakpoints in chromosome 6 were different, and we could not identify a recurring rearrangement. Duplication of the abnormal 6 was found in cases 7 and 8 (Table 1 ). Case 8 represents a 6 -year-old girl with ALL. Both chromosomes 12 were abnormal. G-banding detected a der(12)t(12;17), and FISH and SKY completed the analysis, showing that the patient had the classic $\mathrm{t}(12 ; 21)$, with an ETV6-CBFA2 fusion confirmed by FISH. Surprisingly, in addition to the normal chromosome 6, two der(6) with a complex $\operatorname{der}(6) \mathrm{t}(6 ; 21) \mathrm{t}(12$; 21) were detected (Fig. 3). ETV6 was deleted in the $\operatorname{der}(12) \mathrm{t}(12 ; 17)$.

Figure 3. Examples of the analysis of cells from two patients. A: Patient 8. Fluorescence in situ hybridization and spectral karyotyping analysis showing the classic ETV6-CBFA2 fusion on the $\operatorname{der}(2 \mathrm{I})$ and two $\operatorname{der}(6) \mathrm{t}(6 ; 2 \mathrm{I}) \mathrm{t}(\mid 2 ; 2 \mathrm{I})$. In the upper left panel, the AMLI probe (red) from chromosome 21 labels the $\operatorname{der}(21)$, both $\operatorname{der}(6)$ chromosomes, and the $\operatorname{der}(12)$. There is no normal chromosome 2I. The ETV6 probe (green) labels the $\operatorname{der}(2 \mathrm{I})$ and both $\operatorname{der}(6)$ chromosomes; it is deleted from the $\operatorname{der}(12)$. There is no normal chromosome 12. The upper right panel shows with the CEP6 probe (red) that there is one normal 6 and two der(6) chromosomes. The painting probe for chromosome 12 (green) labels both $\operatorname{der}(6)$, one $\operatorname{der}(2 \mid)$, the $\operatorname{der}(\mid 2) t(|2 ;| 7)$, and the $\operatorname{der}(12) t(12 ; 2 I)$ chromosomes. Bottom SKY classified image shows involvement of chromosomes 6,12 , and 21 in a complex rearrangement. B: The lower set of images represent SKY analysis of patient 5. Reverse 4'6-diamidino-2-phenylindole dihydrochloride (DAPI), spectral, and classified images are shown. The reverse DAPI image is at bottom left, the spectral image is in the upper left, and the classified image is in the upper right. The abnormal chromosomes are identified with arrows. The karyotype using the classified image is shown in the lower right. 


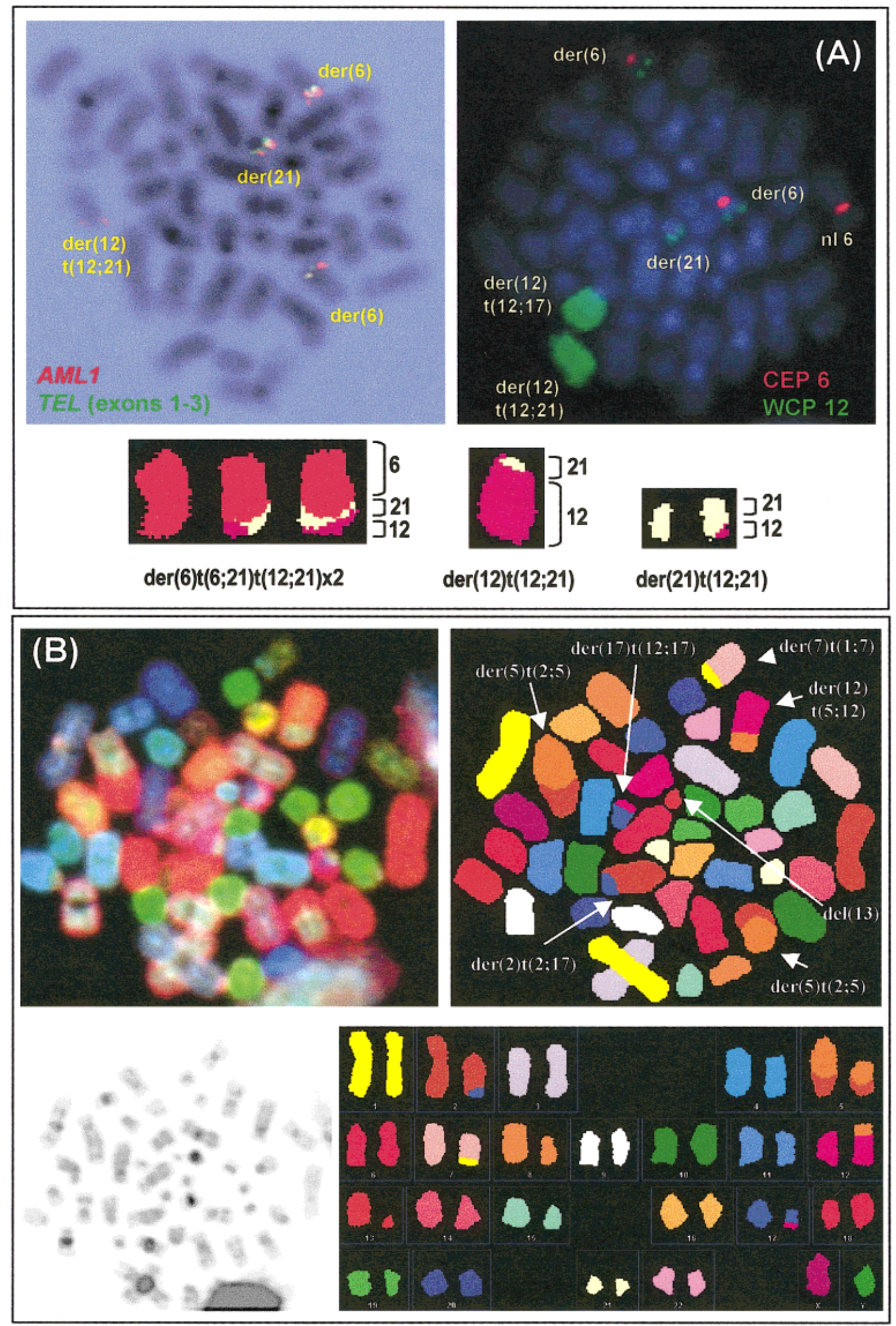


TABLE 3. Review of the Literature of the Cases Reported With Reciprocal Translocations Involving ETV6*

\begin{tabular}{|c|c|c|}
\hline TEL band partner & Diagnosis & Reference $^{\mathrm{a}}$ \\
\hline Ip36 & MDS & Odero et al. (200I) \\
\hline Iq2 I (ARNT) & AML & Berger et al. (1997), Salomon-Nguyen et al. (2000) \\
\hline Iq25 (ARG) & AML & Sato et al. (1997), Cazzaniga et al. (1999) \\
\hline $2 q 31$ & NHL-B & Kobayashi et al. (1994) \\
\hline $3 q 26(E V I I)$ & AML, MDS & Raynaud et al. (1996), Peeters et al. (1997b), Streubel et al. (1998) \\
\hline $4 q 12$ (CHIC2/BTL) & AML & Andreasson et al. (1998), Cools et al. (1999) \\
\hline $4 q 22$ & AML & Odero et al. (200I) \\
\hline $5 q 13$ & AML, ALL & Kobayashi et al. (1994) \\
\hline $5 q^{3} 1$ (ACS2) & $\mathrm{CML}$ & Wlodarska et al. (1997), Yagasaki et al. (1 999) \\
\hline $5 q 33$ (PDGFR $\beta$ ) & AML, MDS & Golub et al. (1994), Höglund et al. (1996), Sato et al. (1997) \\
\hline $6 p 11-p 12$ & MDS & Streubel et al. (1998) \\
\hline $6 \mathrm{p} 21$ & CLL & Odero et al. (200I) \\
\hline $6 p 2 ? 5$ & ALL & Kobayashi et al. (1994) \\
\hline $6 \mathrm{q} 21$ & ALL & Raimondi et al. (1997) \\
\hline $6 q 23$ (STL) & ALL & Suto et al. (1997) \\
\hline $6 \mathrm{q} 25$ & MDS & Odero et al. (200I) \\
\hline $7 \mathrm{p} 12$ & ALL & Wlodarska et al. (1998) \\
\hline $7 p 15$ & AML & Wlodarska et al. (1998) \\
\hline $7 q 22$ & MDS & Tosi et al. (1998) \\
\hline $7 q 32$ & AML & Satake et al. (1999) \\
\hline $7 q 36$ & AML & Tosi et al. (1998), Wlodarska et al. (1998), Slater et al. (I999), Tosi et al. (2000) \\
\hline $8 \mathrm{p} 21$ & ALL & Raimondi et al. (1997) \\
\hline $8 q 11$ & MDS & Kobayashi et al. (1994) \\
\hline $9 \mathrm{p} 24(J A K 2)$ & ALL, CML & Berger et al. (1997), Peeters et al. (1997a) \\
\hline $9 q 11$ & ALL & Tosi et al. (1998) \\
\hline $9 \mathrm{q} 34(A B L)$ & ALL, CML, AUL & Kobayashi et al. (1994), Papadopoulos et al. (1995), Andreasson et al. (1997) \\
\hline I Iq2? & AML & Andreasson et al. (1998) \\
\hline $12 \mathrm{q} 24$ & AML & Odero et al. (200I) \\
\hline $13 q 12(C D X 2)$ & AML, ALL & Streubel et al. (1998), Tosi et al. (1998), Wlodarska et al. (1998), Chase et al. (1999) \\
\hline $14 q 22$ & AUL & Kobayashi et al. (1994) \\
\hline I5q25 (TRKC) & AML & Eguchi et al. (1999) \\
\hline $16 q 24$ & MDS & Sato et al. (1997) \\
\hline $17 p \mid 3$ & AML, MDS & Kobayashi et al. (1994) \\
\hline $17 q 12$ & MDS & Odero et al. (200I) \\
\hline $17 q 25$ & AML & Wlodarska et al. (1998) \\
\hline $19 q 13$ & CML & Kobayashi et al. (1994) \\
\hline 2 Iq22 (AMLI) & AML & Golub et al. (1995), Romana et al. (1995) \\
\hline $22 q I I(M N I)$ & AML & Buijs et al. (1995) \\
\hline $22 q 12$ & AML & Höglund et al. (1996) \\
\hline $22 q 13.1$ & AML & Kobayashi et al. (1994) \\
\hline $\mathrm{Xq} 28$ & MDS & Berger et al. (1997) \\
\hline
\end{tabular}

*MDS, myelodysplastic syndromes; AML, acute myeloid leukemia; NHL-B, non-Hodgkin lymphoma, B cell; ALL, acute lymphoblastic leukemia; CML, chronic myelogenous leukemia; CLL, chronic lymphocytic leukemia; AUL, acute undifferentiated leukemia.

${ }^{a}$ Cloned ETV6 band partners are highlighted in bold type.

Another complex translocation $\mathrm{t}(2 ; 2 ; 5 ; 12 ; 17)$ involving ETV6 was detected in a patient diagnosed as having MDS refractory anemia with excess blasts (RAEB) (case 5). FISH with ETV6 cosmids showed that this gene was involved, with the breakpoint between exons 2 and 3 (Table 2). The partner bands were $5 \mathrm{q} 31$ and $17 \mathrm{q} 12$. The ETV6 partner gene on $5 \mathrm{q} 31$ could be ACS2 (Yagasaki et al., 1999). This is the first time that band 17q12 has been reported to be involved in rearrangements with ETV6. SKY confirmed the translocation and identified the $\operatorname{add}(5)$ as a $\operatorname{der}(5) t(2 ; 5)$ (Fig. 3). The partial loss of chromosome 5 material seen in this patient is a recurrent event in cases of myeloid disorders. The fact that ETV6 rearrangements occurred as subclones in two cases (cases 1 and 5) suggests that these ETV6 translocations could be secondary abnormalities in myeloid malignancies. FISH analysis with the other probes located on $12 \mathrm{p} 12.1$ to $12 \mathrm{p} 13.3$ showed no $12 \mathrm{p}$ deletions in these cases.

The breakpoints in ETV6 in our cases were between exons 1 and 2 (one case) and exons 2 and 3 (five cases), upstream from the exons coding for the 
HLH domain, and between exons 3 and 5 (two cases) and exons 5 and 8 (one case) (Table 2 and Fig. 1). In three patients (cases 2, 3, and 6), the location of the breakpoint was confirmed by sequencing (data not shown). It is difficult to predict the molecular consequences of these rearrangements, owing to the variety of mechanisms described in the 13 fusion genes cloned (Golub et al., 1994, 1995; Romana et al., 1995; Buijs et al., 1995; Papadopoulos et al., 1995; Peeters et al., 1997a,b; Suto et al., 1997; Cazzaniga et al., 1999; Chase et al., 1999; Cools et al., 1999; Eguchi et al., 1999; Yagasaki et al., 1999; Iijima et al., 2000; SalomonNguyen et al., 2000). In the six cases in which the 12 p13 breakpoint occurred upstream from the exons coding for the HLH domain, in intron 1 or 2, the oncogenic potential of some of these translocations could result from the ETV6 promoter's driving the transcription of the partner gene, as has been suggested for the ETV6-MDS1/EVI1 fusion (Peeters et al., 1997b). The importance of the ETV6 gene in hematopoiesis makes these results interesting for future studies. Identification of some of the new fusion partner genes is in progress.

Although the same fusion transcript has been found in the translocations involving ETV6 in both myeloid and lymphoid leukemias (Peeters et al., 1997a), all the cases that have been cloned with breakpoints between exons 2 and 4 are myeloid neoplasias (Buijs et al., 1995; Peeters et al., 1997a,b; Chase et al., 1999). In our series, the breakpoints of the cases of myeloid malignancies were between exons 2 and 5 , whereas they were outside this region in the two lymphoid cases (Table 2). ETV6 and MLL are unique in having more than 40 partner genes involved in translocations leading to fusion genes. Our present data, along with other of our data and the data of other researchers, suggest that ETV6 is involved in 41 translocations (Table 3).

By combining G-banding, FISH, and SKY analysis, we redefined the aberrations described by G-banding. FISH allowed the identification of six new ETV6 translocations. In all instances, the breakpoints of chromosomal rearrangements were identified by comparing the banding and painting patterns, but SKY confirmed the FISH findings and clarified the abnormalities in two patients with complex karyotypes. This approach allowed the identification of hidden translocations in six cases. Thus, complete characterization of the samples was achieved by using all three techniques in combination.

\section{ACKNOWLEDGMENTS}

We thank M. Le Beau, D. Roulston, and M. Isaacson for access to data management and for the patient karyotypic data. Research was supported by the Departamento de Salud del Gobierno de Navarra and Fundacion Empresa-Universidad de $\mathrm{Na}$ varra (Spain) (M.D.O.) and by the National Cancer Institute (CA42557 to J.D.R.), the G. Harold and Leila Y. Mathers Charitable Foundation (J.D.R.), and the Spastic Paralysis Foundation, Illinois-Eastern Iowa District of Kiwanis International (J.D.R.).

\section{REFERENCES}

Andreasson P, Johansson B, Carlsson M, Jarlsfelt I, Fioretos T, Mitelman F, Höglund M. 1997. BCR/ABL-negative chronic myeloid leukemia with ETV6/ABL fusion. Genes Chromosomes Cancer 20:299-304.

Andreasson P, Johansson B, Billström R, Garwicz S, Mitelman F, Höglund M. 1998. Fluorescence in situ hybridization analyses of hematologic malignancies reveal frequent cytogenetically unrecognized 12 p rearrangements. Leukemia 12:390-400.

Baens M, Peeters P, Guo C, Aerssens J, Marynen P. 1996. Genomic organization of TEL: the human ETS-variant gene 6. Genome Res 6:404-413.

Berger R, Le Coniat M, Lacronique V, Daniel MT, Lessard M, Berthou C, Marynen P, Bernard O. 1997. Chromosome abnormalities of the short arm of chromosome 12 in hematopoietic malignancies: a report including three novel translocations involving the TEL/ETV6 gene. Leukemia 11:1400-1403.

Buijs A, Sherr S, van Baal S, van Bezouw S, van der Plas DC, Geurts van Kessel A, Riegman P, Lekanne Deprez R, Zwarthoff E, Hagemeijer A, Grosweld G. 1995. Translocation t(12;22)(p13;q11) in myeloproliferative disorders results in fusion of the ETS-like TEL gene on $12 \mathrm{p} 13$ to the $M N 1$ gene on 22q11. Oncogene 10: 1511-1519.

Cazzaniga G, Tosi S, Aloisi A, Giudici G, Daniotti M, Pioltelli P, Kearney L, Biondi A. 1999. The tyrosine kinase abl-related gene $A R G$ is fused to ETV6 in an AML-M4Eo patient with a $\mathrm{t}(1$; 12)(q25;p13): molecular cloning of both reciprocal transcripts. Blood 94:4370-4373.

Chase A, Reiter A, Burci L, Cazzaniga G, Biondi A, Pickard J, Roberts IA, Goldman JM, Cross NC. 1999. Fusion of ETV6 to the caudal-related homeobox gene $C D X 2$ in acute myeloid leukemia with the $\mathrm{t}(12 ; 13)(\mathrm{p} 13 ; \mathrm{q} 12)$. Blood 93:1025-1031.

Cools J, Bilhou-Nabera C, Wlodarska I, Cabrol C, Talmant P, Bernard P, Hagemeijer A, Marynen P. 1999. Fusion of a novel gene, $B T L$, to ETV6 in acute myeloid leukemias with a $\mathrm{t}(4 ; 12)(\mathrm{q} 11-\mathrm{q} 12$; p13). Blood 94:1820-1824.

Eguchi M, Eguchi-Ishimae M, Tojo A, Morishita K, Suzuki K, Sato Y, Kudoh S, Tanaka K, Setoyama M, Nagamura F, Asano S, Kamada N. 1999. Fusion of ETV6 to neurotrophin-3 receptor TRKC in acute myeloid leukemia with $\mathrm{t}(12 ; 15)(\mathrm{p} 13 ; \mathrm{q} 25)$. Blood 93:1355-1363.

Golub TR, Barker GF, Lovett M, Gilliland DG. 1994. Fusion of $P D G F$ receptor beta to a novel ets-like gene, tel, in chronic myelomonocytic leukemia with $\mathrm{t}(5 ; 12)$ chromosomal translocation. Cell 77:307-316.

Golub TR, Barker GF, Bohlander SK, Hiebert SW, Ward DC, Bray Ward P, Morgan E, Raimondi SC, Rowley JD, Gilliland DG. 1995. Fusion of the TEL gene on 12 p13 to the AML1 gene on $21 \mathrm{q} 22$ in acute lymphoblastic leukemia. Proc Natl Acad Sci USA 92:4917-4921.

Höglund M, Johansson B, Pedersen-Bjergaard J, Marynen P, Mitelman F. 1996. Molecular characterization of $12 \mathrm{p}$ abnormalities in hematologic malignancies: deletion of KIP1, rearrangement of TEL, and amplification of CCND2. Blood 87:324-330.

Iijima Y, Ito T, Oikawa T, Eguchi M, Eguchi-Ishimae M, Kamada N, Kishi K, Asano S, Sakaki Y, Sato Y. 2000. A new ETV6/TEL partner gene, $A R G$ (ABL-related gene or ABL2), identified in an AML-M3 cell line with a $\mathrm{t}(1 ; 12)(\mathrm{q} 25 ; \mathrm{p} 13)$ translocation. Blood 95:2126-2131.

Kobayashi H, Montgomery KT, Bohlander SK, Adra CN, Lim BL, Kucherlapati RS, Donis-Keller H, Holt MS, Le Beau MM, Row- 
ley JD. 1994. Fluorescence in situ hybridization mapping of translocations and deletions involving the short arm of human chromosome 12 in malignant hematologic diseases. Blood 84:34733482 .

Mitelman F, editor. 1995. ISCN (1995). An international system for human cytogenetic nomenclature. Basel: S. Karger.

Mitelman F. 1998. Catalog of chromosome aberrations in cancer. CD ROM version. New York: Wiley-Liss.

Papadopoulos P, Ridge SA, Boucher CA, Stocking C, Wiedemann LM. 1995. The novel activation of $A B L$ by fusion to an ets-related gene, TEL. Cancer Res 55:34-38.

Peeters P, Raynaud SD, Cools J, Wlodarska I, Grosgeorge J, Philip P, Monpoux F, Van Rompaey L, Baens M, Van den Berghe H, Marynen P. 1997a. Fusion of TEL, the ETS-variant gene 6 (ETV6), to the receptor-associated kinase JAK2 as a result of $\mathrm{t}(9 ; 12)$ in a lymphoid and $\mathrm{t}(9 ; 15 ; 12)$ in a myeloid leukemia. Blood 90:2535-2540.

Peeters P, Wlodarska I, Baens M, Criel A, Selleslag D, Hagemeijer A, Van den Berghe H, Marynen P. 1997b. Fusion of ETV6 to MDS1/EVI1 as a result of $\mathrm{t}(3 ; 12)(\mathrm{q} 26 ; \mathrm{p} 13)$ in myeloproliferative disorders. Cancer Res 57:564-569.

Pietenpol JA, Bohlander SK, Sato Y, Papadopoulos N, Liu B, Friedman C, Trask BJ, Roberts JM, Kinzler KW, Rowley JD, Vogelstein B. 1995. Assignment of the human p27Kip1 gene to 12 p13 and its analysis in leukemias. Cancer Res 55:1206-1210.

Raimondi SC, Shurtleff SA, Downing JR, Rubnitz J, Mathew S, Hancock M, Pui CH, Rivera GK, Grosveld GC, Behm FG. 1997. $12 \mathrm{p}$ abnormalities and the TEL gene (ETV6) in childhood acute lymphoblastic leukemia. Blood 90:4559-4566.

Raynaud SD, Baens M, Grosgeorge J, Rodgers K, Reid CD, Dainton M, Dyer M, Fuzibet JG, Gratecos N, Taillan B, Ayraud N, Marynen P. 1996. Fluorescence in situ hybridization analysis of $\mathrm{t}(3 ; 12)(\mathrm{q} 26 ; \mathrm{p} 13)$ : a recurring chromosomal abnormality involving the TEL gene (ETV6) in myelodysplastic syndromes. Blood 88: 682-689.

Romana SP, Mauchauffé M, Le Coniat M, Chumakov I, Le Paslier D, Berger R, Bernard OA. 1995. The $t(12 ; 21)$ of acute lymphoblastic leukemia results in a TEL-AML1 gene fusion. Blood 85: 3662-3670.

Rowley JD, Diaz MO, Espinosa R III, Patel YD, van Melle E, Ziemin S, Taillon-Miller P, Lichter P, Evans GA, Kersey JH. 1990. Mapping chromosome band 11q23 in human acute leukemia with biotinylated probes: identification of 11q23 translocation breakpoints with a yeast artificial chromosome. Proc Natl Acad Sci USA 87:9358-9362.

Rowley JD, Reshmi S, Carlson K, Roulston D. 1999. Spectral karyotype analysis of T-cell acute leukemia. Blood 93:2038-2042.

Salomon-Nguyen F, Della-Valle V, Mauchauffe M, Busson-Le Coniat M, Ghysdael J, Berger R, Bernard OA. 2000. The t(1;12)(q21; p13) translocation of human acute myeloblastic leukemia results in a TEL-ARNT fusion. Proc Natl Acad Sci USA 97:6757-6762.

Satake N, Maseki N, Nishivama M, Kobayashi H, Sakurai M, Inaba H, Katano N, Horikoshi Y, Eguchi H, Miyake M, Seto M, Kaneko
Y. 1999. Chromosome abnormalities and MLL rearrangements in acute myeloid leukemia of infants. Leukemia 13:1013-1017.

Sato Y, Bohlander SK, Kobayashi H, Suto Y, Davis EM, Espinosa R III, Hoopes R, Montgomery KT, Kucherlapati RS, Le Beau MM, Rowley JD. 1997. Heterogeneity in the breakpoints in balanced arrangements involving band 12p13 in hematologic malignancies identified by fluorescence in situ hybridization: TEL (ETV6) is involved in only one half. Blood 90:4886-4893.

Slater RM, van Drunen E, Kroes WG, Weghuis DO, van den Berg E, Smit EM, van Wering E, Hahlen K, Beverloo HB. 1999. $\mathrm{t}(7 ; 12)(\mathrm{q} 36 ; \mathrm{p} 13)$ : a new translocation involving ETV6 associated with a poor prognosis in myeloid malignancies of very young children. Blood 94:501a.

Streubel B, Sauerland C, Heil G, Freund M, Bartels H, Lengfelder E, Wandt H, Ludwig WD, Nowotny H, Baldus M, GrothausPinke B, Buchner T, Fonatsch C. 1998. Correlation of cytogenetic, molecular cytogenetic, and clinical findings in 59 patients with ANLL or MDS and abnormalities of the short arm of chromosome 12. Br J Haematol 100:521-533.

Suto Y, Sato Y, Smith SD, Rowley JD, Bohlander SK. 1997. A $\mathrm{t}(6 ; 12)(\mathrm{q} 23 ; \mathrm{p} 13)$ results in the fusion of ETV6 to a novel gene, $\mathrm{STL}$, in a B-cell ALL cell line. Genes Chromosomes Cancer 18:254-268.

Tosi S, Giudici G, Mosna G, Harbott J, Specchia G, Grosveld G, Privitera E, Kearney L, Biondi A, Cazzaniga G. 1998. Identification of new partner chromosomes involved in fusions with the ETV6 (TEL) gene in hematologic malignancies. Genes Chromosomes Cancer 21:223-229.

Tosi S, Giudici G, Harbott J, Teigler-Schlegel A, Haas OA, PircDanoewinata H, Harrison CJ, Biondi A, Cazzaniga G, Kempski H, Scherer SW, Kearney L. 2000. t(7;12)(q36;p13), a new recurrent translocation involving ETV6 in infant leukemia. Genes Chromosomes Cancer 29:325-332.

Wang LC, Swat W, Fujiwara Y, Davidson L, Visvader J, Kuo F, Alt FW, Gilliland DG, Golub TR, Orkin SH. 1998. The TEL/ETV6 gene is required specifically for hematopoiesis in the bone marrow. Genes Dev 12:2392-2402.

Wlodarska I, Aventin A, Ingles-Esteve J, Falzetti D, Criel A, Cassiman JJ, Mecucci C, Van den Berghe H, Marynen P. 1997. A new subtype of pre-B acute lymphoblastic leukemia with $\mathrm{t}(5 ; 12)(\mathrm{q} 31 \mathrm{q} 33 ; \mathrm{p} 12)$, molecularly and cytogenetically distinct from $\mathrm{t}(5 ; 12)$ in chronic myelomonocytic leukemia. Blood 89:1716-1722.

Wlodarska I, La Starza R, Baens M, Dierlamm J, Uyttebroeck A, Selleslag D, Francine A, Mecucci C, Hagemeijer A, Van den Berghe H, Marynen P. 1998. Fluorescence in situ hybridization characterization of new translocations involving TEL (ETV6) in a wide spectrum of hematologic malignancies. Blood 91:1399-1406.

Yagasaki F, Jinnai I, Yoshida S, Yokoyama Y, Matsuda A, Kusumoto S, Kobayashi H, Terasaki H, Ohyashiki K, Asou N, Murohashi I, Bessho M, Hirashima K. 1999. Fusion of TEL/ETV6 to a novel ACS2 in myelodysplastic syndrome and acute myelogenous leukemia with $\mathrm{t}(5 ; 12)(\mathrm{q} 31 ; \mathrm{p} 13)$. Genes Chromosomes Cancer 26: 192-202. 